\title{
Az ISKOLA BIZALMI KLÍMÁJÁNAK VERBÁLIS MARKEREI
}

\author{
SASS JUDIT* - BODNÁR ÉVA \\ Budapesti Corvinus Egyetem
}

A szervezeti bizalom klíma kvalitatív vizsgálatát Ötperces beszédminta elemző eljárás (Magaña et al. 1986) segítségével végeztük el középszintű oktatási intézményekben $(N=112)$. Az interjúk szövegét Atlas.ti programmal előzetesen kialakított kategóriák (érzelmi valencia, kényszer, szándék, közösség) alapján elemeztük, az eredményeket öszszevetettük az érzelmi klíma kérdőív (Wiesenfeld et al. 1997) alskáláival.

$\mathrm{A} z$ azonosított nyelvi markerek a bizalom kognitív és érzelmi alapjai szerint eltértek. A kiszámíthatóság jelei: a kedvező érzelmi viszonyulás, a vezetői kényszer elfogadása, a külső szakmai kényszerek és a diákokkal kapcsolatos kényszerek említésének hiánya. Az érzelmi bizalomalapok markerei: a többes szám első személy használata, a kollegiális és a fizikai feltétel kényszerek hiánya, valamint az autonómiaérzet a diákokkal a szakmai munka kapcsán.

Kulcsszavak: iskolai bizalom klíma, észlelt kontroll, Ötperces beszédminta eljárás, bizalom verbális markerei

The qualitative analysis of organizational trust climate was carried out using a Fiveminute Speech Sample Method (Magaña et al. 1986) in intermediate level education institutions $(N=112)$. The corpus of the interviews were analyzed with Atlas.ti program with help of previously identified categories of trust-signals (emotional valence, coercion, intent, community), the results were compared with subscales of organizational climate questionnaire (Wiesenfeld et al. 1997). The identified linguistic markers differed according to cognitive and emotional bases of trust.

Signs of predictability were: a favorable emotional valence, acceptance of executive coercion, lack of external professional and student-related constraints. Markers of emotional trust were the use of the first person plural, the lack of collegial and physical constraints, and the sense of autonomy with students and professional work.

Keywords: school trust climate, perceived control, Five Minute Speech Sample Procedure, verbal markers of trust

\footnotetext{
*evelező szerző: Sass Judit, Budapesti Corvinus Egyetem, 1089 Budapest, Fővám tér 8.

E-mail: Judit.sass@uni-corvinus.hu
} 


\section{$\mathrm{A} z$ iskola bizalmi klímája}

A szervezeti bizalom kutatásának egyik mára elfogadottá vált megállapítása, hogy a bizalomnak kognitív és affektív összetevői is vannak (McAllister 1995). A szervezeti bizalom esetén mind az egyének, mind a társas rendszerek szintjén megjelenhet a két összetevő, kölcsönösen erősítve egymást, bár a kognitív oldal csoportszinten relevánsabbnak tekintett (Costa-Fulmer-Anderson 2017). Ugyanakkor a bizalmat az iskolai szervezeti klíma kutatásai a klíma közösségi oldalánál a személyközi kapcsolatok kiemelt jellemzőjének tekintik (Wang-Degol 2016), és a társas rendszerek emocionális klímáját kutatók szerint is lényeges összetevője a pozitív érzelmi klímának (De Rivéra 1992). A fentiek alapján a szervezeti bizalmat a tagok által osztott észlelésnek tekintjük és a szervezeti klíma részeként, a „bizalom klímájaként” vizsgáljuk.

$\mathrm{A} z$ iskolai szervezeti klíma vizsgálatait áttekintő Wang és Degol (2016) megállapítják, hogy a klímavizsgálatok több mint 90\%-a kérdőíves mérésen alapul, nagyon ritkák a mélyebb megértést segítő kvalitatív megközelítések. Lyon, Möllering és Saunders (2015) a bizalomkutatásokra vonatkozó áttekintésükben számos kvalitatív módszert említ a csoportszintü, etnográfiai vizsgálatokban: többek között az interjút, a megfigyelést, a dokumentumelemzést, valamint azokat a kutatásokat, amelyek az interjúk nem nyelvi jeleinek vagy az érzelmi válaszainak elemzése alapján tesznek megállapításokat a bizalomra vonatkozóan.

Vizsgálatunkban arra vállalkozunk, hogy az egyéni szinten észlelt szervezeti bizalom nyelvi jelzéseit azonosítsuk és összevessük kvantitatív módszerekkel nyert adatokkal. A bizalmi kapcsolat sajátosságait figyelembe véve olyan interjútechnikát alkalmazunk, amely a fejlődési vizsgálatokban és családterápiában elfogadott eljárás a kapcsolatok érzelmi jellegének mérésére (Magana et al. 1986; Sher-Censor 2015).

A formális kapcsolati bizalom kvalitatív mérésének korábbi példái között említhető Gambetta és Hamill (2005) vizsgálata, ahol interjúkat készítettek a taxis-utas bizalom forrását keresve. Breeman (2012) szintén hermeneutikai megközelítéssel vizsgálja, milyen okból bíznak meg az emberek egymásban vagy a szervezetben. Breeman vizsgálatában a nyelvi megformálásra is utal, például 2006-os munkájában a „we-mode” használatát tekinti a bizalom kifejezésének élelemiszer-ellátás vonatkozásában. A többes szám első személy használata szintén bizalommegalapozónak tekintett Fiolnál (2002), aki a bizalomformálás retorikai eszközeként említi az inkluzív szóhasználatot a közös identitás jelzésével.

\section{A szervezeti bizalom alapjai}

A megbízhatóság megítélésénél Mayer, Davis és Schoorman (1995) integratív modellje alapján három tényezőből indultunk ki: a bizalomkapó adott területen megmutatkozó képességeiböl, a partner hitéből a „jószándékra” vonatkozóan és az észlelt integritásból. Társas rendszereknél a viselkedést meghatározó, függést biztonságossá tevő személytelen struktúrák és szabályok és azok vezetői képviselete, érvényesítése biztosítja a megbízhatóságot, koordinációt (McKnight-Chervany 1996).

„A szervezeti bizalmat olyan, a szervezeti tagok által osztott hitnek tekintjük, amely az egyén átélt vagy észlelt szervezeti tapasztalatainak interpretációja nyomán alakul, és a szervezet mint részekből álló rendszer megbízhatóságára vonatkozó pozitív elvárásokat 
foglal magába. Összetevői: 1) A „bejósolhatóság”, ami a szervezeti folyamatok, működéskonzisztenciájának, stabilitásának tapasztalatából származik. 2) A „megbízhatóság” a szervezeti működés során kapott ígéretek, vállalt kötelezettségek betartásának tapasztalatból származó elvárás. 3) A ,jóindulat” a rendszer és részei egyénnel kapcsolatos, önérdeken túli, segítő, törődő, gondoskodó és igazságos működésének észleléséből származó elvárás. (Sass 2008.)

A bizalom a szervezetben mint társas tőke elősegíti és kiszámíthatóvá teszi az interakciókat, feleslegessé teszi a kontroll gyakorlását (Martínez-Tur-Peiró 2009). Costa, Fulmer és Anderson (2017) a csoportszintű bizalommal kapcsolatos kutatásokat összegző áttekintésükben a csoportbizalom két, egymással kölcsönösen összefüggő szintjének vizsgálatát ajánlják. Egyrészt befolyásolja a csoportszintű bizalmat a tagok közötti személyközi bizalom. Másrészt a csoporttagoknál a csoport megbízhatóságára vonatkozóan is kialakul észlelés. Amennyiben létrejön az egyetértés, osztott hit a tagoknál, ez befolyásolja a csoport szintjén a várakozásokat és a sebezhetőség vállalásának hajlandóságát. Ugyanakkor hangsúlyoznunk kell, hogy a bizalom szubjektív észlelés, nem feltétele a tagok egyetértése, bár befolyásolhatja az egyéni észlelést a konszenzusos ítélet (Breeman 2012). A szervezeti kontextusban a bizalom személyközi és csoportiszintü folyamatai kölcsönösen hatnak egymásra, és a szervezeti, csoport- és egyéni tényezők egyaránt befolyásolják az egyéni észlelésben megjelenő szervezeti bizalmat.

A szervezeti bizalom alakulására vonatkozóan két modell található a szervezeti kutatásokban. Chan kompozíciós modelljében (idézi Costa-Fulmer-Anderson 2017) a tagok bizalomszintjének felhalmozódásaként értelmezi a csoport-/ szervezeti bizalmat, míg az emergens modell (pl. Shamir-Lapidot 2003) az interakciók és dinamika nyomán formálódó állapotot feltételez. A tagok közötti bizalomaszimmetriák alacsony szintje kedvező hatású a bizalom alakulására és ezzel a teljesítményre. A bizalom alakulását a közös jelentésadás, a csoporton belüli hasonlóság is elősegíti (Costa-Fulmer-Anderson 2017). Kozlowski és munkatársai (2013, idézi Costa-Fulmer-Anderson 2017) az emergens modell alapján vizsgálja a személyközi bizalom és csoportbizalom elözményeit és következményeit, és a két szint egymásra hatását, figyelembe véve a szervezeti kontextust (pl. struktúra, kultúra, HR-gyakorlat) is. Martínez-Tur és Peiró (2009) a szervezeti bizalom epizodikus megközelítésével szintén a bizalom forrásait, kontextusát és következményeit vizsgálta, szintén elkülönítve az egyéni és diádikus közvetlen forrásokat és a csoport-, szervezetszintü tényezőket.

Az epizódmegközelítés szerint egy adott jelenség, például a bizalom vonatkozásában rendelkezünk egyfajta tudással arra vonatkozóan, hogy milyen prototipikus eseménysorozat jellemzi a folyamatot (Martínez-Tur-Peiró 2009). A bizalom bemutatására, látható kifejezésére vonatkozóan az adott szociális közegben és helyzetben a szereplők között létrejönnek megegyezések, társas konvenciók. A normatív elemek közvetítik a kontextushoz kapcsolódó elvárásokat és szankciókat a bizalom kifejezése kapcsán. Ezek bejósolhatóvá teszik a résztvevők számára, hogy mi tekinthető megfelelőnek, mikor, hol, mit kell kifejezniük és mire számíthatnak a többiek részéről (Matsumoto 1990). Mivel a bizalom a múltbeli tapasztalatokon alapul, elsősorban az előzményekre fókuszál az 1. táblázatban található áttekintés. 
1. táblázat: A szervezeti bizalmat befolyásoló tényezők szintek szerint

\begin{tabular}{l|l}
\hline Egyéni és személyközi szint & Csoport- és szervezeti szint \\
\hline Bizalomadó: & Csoport, szervezeti jellemzök: \\
- bizalomadási hajlam, személyiség (extra- & - összetétel homogenitása, feladatfüggés \\
verzió, barátságosság és érzelmi stabilitás) & mértéke \\
- kapcsolati tapasztalatok & - kapcsolatok erőssége, sürüsége \\
- kontrollérzetet támogató pozitív hangulat & -vezetés: világos célok, \\
- kulturális háttértényezők & - klíma: kölcsönös tiszteletet, támogatás \\
& - kultúra: elfogadott normák, elvárások, \\
& értékek \\
\hline Bizalmat kapó: & Kontextuális tényezök: \\
- képesség, integritás és jóindulat & - szervezeti kultúra: kollaboratív, etikus, \\
- viszonzó múködés & felelös értékek \\
- motiváló, transzformáló vezetés & - munkahely biztonsága \\
& - HRM: motiváló, autonómiát támogató, \\
\hline Kontextuális tényezök: & bevonó, igazságos és méltányos folyamatok \\
- helyzet ismerössége & - struktúra: decentralizált, organikus \\
- bizalomkapó észlelt megbízhatósága & - egység észlelt autonómiája, tagok kölcsönös \\
& függése \\
& - klíma: információmegosztást támogató \\
& innovatív, kooperativ, felhatalmazó \\
\hline
\end{tabular}

Forrás: Costa-Fulmer-Anderson 2017; Martínez-Tur-Peiró 2009 alapján

A szervezeti bizalmat megalapozó korábbi kérdőíves kutatásunk a fentieknek megfelelő bizalomösszetevőket azonosított az egyéni észlelésben. ${ }^{1}$ A komponensek a szervezet tagjai közötti kapcsolatokra, valamint a vezetőre mint a bizalmat kapó személyre (bizalom tárgya) vonatkoztak. Kiemelkedtek az észlelésben a pozitív érzelmeket megalapozó személyközi támogatás (munkatársi, vezetői törődés), valamint a kiszámíthatóságot biztosító, kognitív bizalmat megalapozó egyéni kontrollérzet forrásai, például a vezetői igazságosság, egyéni foglalkoztatási biztonságérzet, szervezeti folyamatokba való beleszólás lehetősége, feladat vonatkozású kompetenciaészlelés (Sass 2005). A felsoroltak alapján kiemelhetők a bizalom meglétét jelző összetevők az egyén észlelésében:

- Pozitív érzelmek, érzelmi viszonyulás: A bizalom kognitív és érzelmi aspektusai személyközi és csoportszinten is jelen vannak. Az osztott értékeken, elfogadott, világos célokon, észlelt személyközi és kulturális értékekben, vagy a vezetői igazságosságban megnyilvánuló tiszteleten és törődésen alapuló magas bizalom támogatja az egyéni pozitív érzelmek megjelenését (Tyler 1989). A világos célállítás nyomán egyéni szinten is észlelhető az énhatékonyság, és a közös célokért tett kooperatív erőfeszítés nyomán észlelt kollektív hatékonyság szintén pozitív érzelmek forrása lehet (Sass 2011).

\footnotetext{
1 A középiskolai kérdőíves bizalomvizsgálatban (Sass 2005) feltárt föbb komponensek: Kölcsönös munkatársi törődés, Egyéni foglalkoztatási biztonságérzet, Vezetői igazságosság, méltányosság, Személyes kontrollérzet (a szervezeti folyamatokkal kapcsolatban), Személyes szükségletek (jóllét, érdekek) biztosítottsága, Kompetenciaérzet.
} 
- Kényszer biánya, szándékolt cselekvés feletti kontrollérzett (önirányítás, autonómia): A bizalom közvetlen előnye a kiszámíthatóság, a döntési részvétel, a világos célok észlelése, az önirányítás lehetősége, ami a bizalom esetén az ellenőrzést feleslegessé teszi, önkéntes engedelmességhez vezet. Mindez fókuszált munkavégzést tesz lehetővé, ami a kooperáció, az információmegosztás támogatásával az egyéni teljesítmény, elégedettség és jóllét növekedésével is jár.

- Közösségi érzés, közös szándékok, érdekek, célokः Csoport és szervezeti szinten a bizalom közvetett előnye a teljesítményt támogató kooperáció, tudásmegosztás és az erőfeszítések közös célokra történő irányítása (nem az egyéni érdekek dominálnak), amit a motiváló, transzformáló (közös célokat vizionáló) vezetői múködés is támogat. Mindez mi-tudatban, az egyénivel szemben a csoport céljainak, érdekeinek, a közös szándékoknak a hangsúlyozásában jelenhet meg. A közös, csoportszintủ érdekeknél a tagok személyes bevonódása mellett az egyéni elképzelések képviselete is megjelenhet, ami innovatív megoldások kialakítását segíti. A csoportbizalomnál jellemző az önkéntes engedelmesség a hatalomnak, feleslegesek a költséges kontrollmechanizmusok ezen a szinten is (Sass 2005, 2011).

\section{Bizalom a szervezetben - a „bizalom klímája”}

A szervezeti bizalom kontextusának tekinthető strukturális tényezők és HR-gyakorlatok mellett, a tagok bizalmát befolyásolják az osztott észlelésben, jelentésadásban megjelenő szervezeti kultúra és klíma jellemzők is (Costa-Fulmer-Anderson 2017). A szervezeti kultúra a szocializáció során elsajátítható, a problémamegoldás, alkalmazkodás elvárt útját bemutató osztott feltevések, értékek és hiedelmek rendszere, míg a klíma a jutalmazottként, elvártként tapasztalt és értékelt irányelvek, gyakorlatok és eljárások, viselkedések összessége (Schneider-Ehrhart-Macey 2013: 362). A bizalom mint a szervezeti klíma része, több szervezeti kutatásban megjelenik. Egyrészt az egyéni teljesítményt fokozó tényezőként, másrészt a csoportszintű érzelmi klíma jellemzőjeként találhatunk vizsgálati eredményeket.

A szervezeti klíma az egyén észlelésében jelenik meg, azonban a tagok egyetértése alapján formálódik és hozzájárul a cselekvés egységéhez, a közös célelérés sikeréhez. A konszenzus mértéke határozza meg a klíma erősségét, de az egység mérete, az interakció, a kommunikációs kapcsolatok sűrűsége, a kölcsönös függés, a kohézió, az azonosulás mértéke, a szervezetben töltött idő, valamint a vezetői viselkedés is befolyást gyakorol rá a vizsgálatok szerint (Schneider-Ehrhart-Macey 2013).

A szervezeti klíma egyik megközelítése segít azonosítani a klíma összetevőit, dimenzióit (Halász 1980; Mullins 1993), míg a fókuszmegközelítés a klíma lehetséges előzményeit és következményeit tárja fel, mivel a klímát a szervezet tagjainak osztott érték-, stratégiai cél irányulása alapján azonosítja (Schneider-Ehrhart-Macey 2013). Ilyen közös célként megjelenhet a kölcsönös bizalom klímája is.

Vizsgálatunk oktatási intézményekre vonatkozik, így a specifikumok figyelembevételéhez az iskola szervezeti klímáját Wang és Degol (2016: 316) alapján határozzuk meg és „a diákok és tanárok közötti interakciókat formáló és az elfogadható iskolai viselkedés és normák paramétereit lefektető osztott hiedelmeket, értékeket és attitüdöket" értjük alatta. Részei a fizikai, érzelmi, szociális és intellektuális biztonságérzet; a támogató és befogadó társas kapcsolatok, interakciók; a tanulói bevonódás és a szociális, érzelmi tanulást 
támogató elvárások, értékek; az elköteleződést, odatartozás-érzést támogató fizikai környezet, valamint az iskolai fejlesztési folyamat, amit a tagok elfogadnak és kölcsönös bizalmukkal támogatnak (Thapa et al. 2013). Wang és Degol (2016) négy klímakomponenst ír le, melyek alapján a bizalom lehetséges tárgyai és fókuszai azonosíthatók:

- biztonságkomponens: az intézményben megélt fizikai, érzelmi biztonság és a fegyelem, rend hatékony és méltányosnak észlelt biztosítottsága;

- közösségkomponens: a résztvevők (diák, tanár, vezető, adminisztrátorok, szülők, közösség) interakcióinak minősége az intézményben;

- oktatáskomponens: a tanulás és tanítás támogatottsága az intézményben;

- intézményikörnyezet-komponens: a szervezeti struktúra, infrastruktúra, felszereltség illeszkedése a tevékenységhez (Wang-Degol 2016).

Lényeges továbbá az oktatási intézmény klímája szempontjából kiemelt szerepű vezető (Halász 1980) megbízhatóságát megalapozó tényezők azonosítása is. Tschannen-Moran és Gareis (2015) szerint az észlelt támogató, felhatalmazó, megközelíthető és igazságos személyközi kapcsolatok mellett, a feladatok vonatkozásában is megnyilvánuló „bizalom kultúrában" ragadható meg a vezető felé irányuló bizalom. Utóbbi a tanulói haladásért érzett kollektív felelősségérzetben, az elvárt szakmai teljesítményben és a közösségi elköteleződésben észlelhető. Az intézményben tehát az elvárások mentén a szervezeti teljesítmény, a hatékony oktatás feltételeként jelenik meg a bizalom.

A bizalom teljesítménynövelő szerepét szervezeti kutatások bizonyítják. A „bizalom klímája" elnevezést Butler (1999) a tárgyalási hatékonyságot vizsgáló szervezeti kutatásában használja. Jellemzői a nagyobb információmegosztási, együttműködési hajlandóság, alacsonyabb óvatosság. Ning és Jin (2009) a szervezeti „bizalom klíma” vizsgálatánál az egyéni szervezeti teljesítményt kedvezően befolyásoló hatást tár fel és két mediáló tényező szerepét bizonyítja. A feladattal kapcsolatos kontrollérzeten alapuló feladatra fókuszáló képességet és a pszichológiai biztonságérzeten alapuló szervezeti tanulást. Ha a szervezet tagja a munkatársak, a vezetés és a felsővezetés működését kiszámíthatónak látja, ha törődést észlel, akkor kevésbé fél a kihasználástól, identitása sérülésétől, ami lehetővé teszi a nyitottságot, új megoldások kipróbálását, a hibázás miatti énképsérülés vállalását.

A „bizalom klíma” fogalommal a társas rendszerek kollektív érzelmi folyamatainak vizsgálatainál is találkozunk. A klíma a tagok és külső szemlélő számára is azonosítható és az adott társas egységet (csoport, szervezet, nemzet) jellemző affektív állapotnak tekinthetö (Parkinson-Fischer-Manstead 2005). Itt a „bizalom klíma” alapja a tagok szilárd hite a szándékok és viselkedés/működés megbízhatóságában, igazságosságában és a képességekben, ami nyitottsághoz, forrásmegosztáshoz és kölcsönös támogatáshoz vezet (Yurtsever-De Rivera 2010).

Az összegzés alapján kiemelhetjük azokat a „bizalomtárgyakat”, akikre, amikre bizalom szempontjából figyelem irányul. A vonatkozó észlelés és annak interpretációja alakítja a szervezet tagjainak bizalommal kapcsolatos elképzeléseit, érzelmeit. A három azonosított bizalomhoz kapcsolódó jel - a pozitív érzelmek, a kényszer hiánya, valamint a közösség érzése és a közös szándék - vonatkozásában kiemelhető a munkatársi csoportok, vezető, diákok, szülők, közvetlen közösség jelentősége. Szintén hozzájárulhat az észlelés tartalmához a fizikai és adminisztratív környezet észlelése, valamint a strukturális jellemzők (feladatelvárások, hatékonysági kritériumok) megítélése az oktatási intézmények klímáját befolyásoló tényezők közül. 


\section{A vizsgálati kérdés és feltevések}

Alábbi vizsgálatunkban arra kerestük a választ, hogy az azonosított bizalomösszetevők vonatkozásában kimutatható-e eltérés a bizalom szintjétől függően a szervezeti tagok egyéni verbális megnyilvánulásai szintjén. Az eltérések nyomán azonosíthatók-e azok a verbális markerek, amelyek a bizalom/bizalomhiány jelzései lehetnek.

A vizsgálat során a résztvevők szervezetre vonatkozó szabad leírásainak tartalomelemzését végeztük el, és összevetettük ezeket az eredményeket a szervezeti bizalom kérdőív eredményeivel. Célunk annak vizsgálata volt, hogy lehetséges-e olyan verbális markereket azonosítani, amelyek az egyéni szintű szervezeti bizalom vonatkozásában megbízható információval szolgálnak. A fenti bizalom-összetevőkre vonatkozó szakirodalmi áttekintés nyomán a tartalomelemzés érzelmi vonatkozású vizsgálatai segítségével azonosítható pozitív érzelmek, a kényszer hiánya és a közösség érzése, a közös szándék vonatkozású nyelvi jelek megjelenése és a szervezeti bizalom szint pozitív együttjárását feltételeztük.

\section{A bizalom klíma verbális jeleinek vizsgálata}

Az adatfelvételére 2015 tavaszán került sor, arra kiképzett pszichológusok, pszichológushallgatók és a tanárképzésben részt vevő oktatók közremüködésével. ${ }^{2}$

\section{A vizsgálati módszerek}

Érzelmi Klíma kérdőív (Clima emocional - Wiesenfeld et al. 1997). A kérdőívben egy általános és nyolc specifikus érzelmiklíma-összetevő szervezeti jellemzőséget ötfokú skálán ítélik meg a válaszadók. A kérdőív arra kérdez rá, hogy a személy megítélése szerint „Milyen az Önök iskolájában a hangulat”, amit nyolc összetevő vonatkozásában értékel a válaszadó. ${ }^{3} \mathrm{~A}$ szervezeti légkör az általánosan megítélt légkör (nagyon rossz vs, nagyon jó) mellett a nyolc vizsgált terület mentén jellemezhető, valamint öt komponens alapján átlagolt pozitív klíma mutató is számolható. Ezek a 1) a reményteli, bizakodó; 2) kölcsönösen támogató; 3) kiszámíthatóan mennek a dolgok; 4) az öröm, bizalom, elégedettség és 5) az emberek szabadon, bátran beszélhetnek jellemzőkre vonatkozó megítélések. A bizalom vonatkozásában ezen összetevők közül a jövőre vonatkozó kedvező, biztonságérzettel járó észlelés („remény, bizakodás”, valamint a „kiszámíthatóság”), a korábbi vizsgálatunkban is azonosított bizalomkomponens volt. - Lásd Sass (2005) vizsgálatában mint Személyes kontrollérzet a szervezetfolyamatoknál komponens. Itt a bizakodás, kiszámíthatóság a

2 Ezúton szeretnénk köszönetet mondani a munkában részt vevő kollégáinknak: Csillik Olgának, Daruka Magdolnának, Lippai Editnek, az elővizsgálatok tartalomelemzését végző Fülöp Évának, valamint az adatfelvételben közremüködő hallgatóinknak: Berecz Brigittának, Bodócs Dórának, Both Eszternek, Déri Melindának, Giriti Petrának, Halász Zsófinak, Honti Eszternek, Nagy Alexnek, Szpodnyi Kittinek, Tasnádi Dórának, Vass Borbála Virágnak.

3 Példa a kérdőív kérdéseire:

Milyen Önöknél a hangulat?

1. reményteli, bizakodó

\begin{tabular}{ccccc}
\hline Egyáltalán nem & Kissé & Közepesen & Eléggé & Nagyon \\
\hline 1 & 2 & 3 & 4 & 5 \\
\hline
\end{tabular}


bizalom egyik összetevőjének tekintett, nem szinonimaként használt kifejezés. Hasonlóan megjelent korábbi vizsgálatunkban az észlelt szervezeti bizalom komponenseként a „kölcsönös támogatás” (Sass 2005: Kölcsönös munkatársi törődés), valamint magának a bizalomhoz társuló kedvező érzelmeknek: „öröm, bizalom, elégedettség” az észlelése, ami a korábbi vizsgálatunkban a Személyes szükségletek biztosítottsága (Sass 2005) mint elégedettségforrás került azonosításra. Továbbá alkalmazható a negatív klíma mutató, amely három területre vonatkozó, szintén átlagolt értékelésből számolható és a fentiek ellentéteként a szervezeten belüli bizalom hiányát is jelezheti. Ezek 1) a félelem, szorongás, aggodalom; 2) az ellenségeskedés, agresszivitás, valamint 3) a szomorúság, passzivitás, rosszkedv.

\section{Beszéljen öt percig szabadon a munkahelyéröl!}

\section{(Five Minutes Speech Sample - FMSS. Magaña et al. 1986)}

A szervezeti bizalomban érzelmi kapcsolatot, lojalitást, kötődést is feltételezett az egyén és a szervezet között. A bizalom szervezeti következményei is hordoznak affektív komponenseket, mint például az elégedettség vagy az elkötelezettség. Ebből a kapcsolati megközelítésből kiindulva a megszokott kérdőíves szervezeti bizalomvizsgálat mellett a kapcsolat érzelmi klímájának értékelésére lehetőséget adó Ötperces beszédminta technika alkalmazásával is megkíséreltük a szervezeti bizalom, a bizalmi klíma vizsgálatát. Az eljárást Gottschalk és Gleser (1969 idézi Magaña et al. 1986) dolgozta ki. Az eljárás célja a válaszadó viszonyulását, érzéseit és észlelését feltárni a válaszadó és kliens kapcsolatára vonatkozóan (Magaña et al. 1986).

\section{A kódolás}

A bizalom alapjainak meghatározásához a pozitív érzelmi megnyilvánulások mellett a kényszerre és szándékra, a közösségi érzésre, közös szándékra vonatkozó tartalomelemzést végeztünk. Az interjúkat Atlas.ti tartalomelemző szoftver segítségével vizsgáltuk, figyelembe véve a tudományos narratív pszichológia elméleti feltevését, miszerint a személy pszichológiai állapotát a történeteinek kompozíciós elvei tükrözik (Ehmann et al. 2014). Az elemzések során felhasználtuk a bizalom jelenléte szempontjából azonosított kontrollérzetre utaló, a NarrCat elemzési szempontjai közt megjelenő intencionalitás/ szándék kategóriát. ${ }^{4}$

$\mathrm{A} z$ érzelmi viszonyulás érkelésének alapja az első teljes mondat/gondolat minősége (pozitív, negatív vagy neutrális), valamint a teljes szöveg alapján a beszélő és a beszéd tárgya közötti kapcsolat valenciája (pozitív, illetve negatív) volt.

Szándékként azonosítottuk az eseteket, amikor kifejezésre kerülő szándékról van szó, a szándéktulajdonítás jelölve van (pl. „azt szeretnék megtanítani”, „azzal a céllal veszünk részt..."). A kategóriában döntően egyéni törekvések, megoldások szerepeltek, a személy vagy a saját akaratot, kontrollt, aktivitást jelezte (pl. „törekedtünk”, „szerettem volna”),

\footnotetext{
4 Az intencionalitásban László et al. (2013) nyomán az elsődlegesen megjelenő szándéktulajdonítást jelöltük meg, azaz az intencionális igéket, a feltételes módot, intencionális főneveket, módhatározókat is. Az elemzéseink során azt is jelöltük, hogy a vizsgálati személy kinek tulajdonítja a cselekvés alakulását, maga választja a cselekvést, önirányítást él át, ahogy az feltételezhető a bizalom jelenléténél, vagy külső kényszerből hajtja végre a cselekvést, azaz elszenvedi azt.
} 
vagy annak lehetőségét fejezte ki (pl. „lehetett”, „rendelkezésre állt”). A sikeres megoldás a kontroll észlelését jelezte, míg a próbálkozás a kontrollérzet hiányát.

Kényszerként azokat az eseteket kódoltuk, amikor az intenció hiánya vagy a kényszerítés-kényszerítettség jelenik meg az interjúban (pl. „én nem akartam”, „,muszáj volt”, ,ezt kellett tennünk"). Elkülönítettük a szövegkörnyezet alapján a kényszereket észlelt forrásuk szerint is, és csoportosítottuk aszerint is, hogy külső vagy belső kényszerről volt-e szó. A kényszer forrásainál megjelentek az iskola, a vezető, a külső vagy belső szakmai megfelelés, az iskolai közösség, az iskola fizikai feltételei, a tanulók, az iskolai adminisztráció, a szülők, kollégák, a saját család, a társadalmi tényezők, a fenntartó. Külső kényszerként jelöltük meg, ha a válaszadó „,kell”, „,muszáj”, „köteles”, „ajánlatos” stb. kifejezéseket használta. Belső kényszerként jelöltük, ha a válaszadó lelkiismereti faktorokat említett.

Közösségi érzésre, közös szándékra utaló kifejezésekhez soroltunk minden olyan választ, amely a közösségre utalást, közös cselekvést tartalmaznak (pl. „közösen csináljuk”, „együtt dolgozunk”), illetve azon válaszokat, amelyek a többes szám első személyt jelzik (pl. „mi”, „velünk”, „nekünk”).

\section{A vizsgálati minta}

A tanári érzelmi igénybevétel vizsgálatokban összesen 17 középfokú oktatási intézmény tanárai vettek részt, jelen elemzésünkben 112 fő teljes adatának (interjú és kérdőív) vizsgálatát végeztük el. Nem került sor az eredmények intézményszintű elemzésére, csak egyéni szintű észlelésekként kezeltük az adatokat. Az eredmények kiértékelése SPSS 22 statisztikai programcsomaggal, a tartalomelemzés Atlas.ti tartalomelemző programmal történt.

\section{Eredmények}

\section{Érzelmi Klima kérdőív eredményei}

A z érzelmi klíma értékelését kérő kérdőív általános klímamegítélést („Az ön iskolájának Általános érzelmi légköre” megítélése ötfokú skálán, ahol az 1 a "nagyon rossz”, az 5 a "nagyon jó”) és nyolc, a társas rendszer hangulatát jellemző pozitív, illetve negatív klímajellemző értékelését kéri ötfokú skálán. (Például „A hangulat reményteli, bizakodó...” értékelése kapcsán a skála: 1) „egyáltalán nem”, 2) „kissé”, 3) „közepesen”, 4) „eléggé”, 5) „nagyon”.) A kilenc mutató mellett az átlagok alapján összesíthető pozitív és negatív klíma mutatók eredményei láthatók az 1. ábrán (lásd kérdőív bemutatásánál).

A z általános megítélés alapján érzelmi légkör inkább kedvezőnek („közepes” és „jó” közötti átlag 3,75) tekinthető. Az egyes elemek összesítése szerint a negatív és pozitív klíma alacsonyabb értékelést kapott. Az általános légkörhöz képest a pozitív klíma vonatkozásában is valamivel alacsonyabb az átlag (3,38, ami a „közepesen” és „eléggé" értékelés közé esik), ezen belül átlag felett jellemzőnek tartott a kölcsönös támogatás és a szabad véleménynyilvánítás, míg kevésbé jellemző az öröm, bizalom, elégedettség és a reményteli, bizakodó légkör és a kiszámíthatóság, azaz a bizalmat megalapozó és jelző észlelések. A válaszadók 56,3\%-ának az átlagnál kedvezőbb az értékelése a pozitív klíma vonatkozásában. 


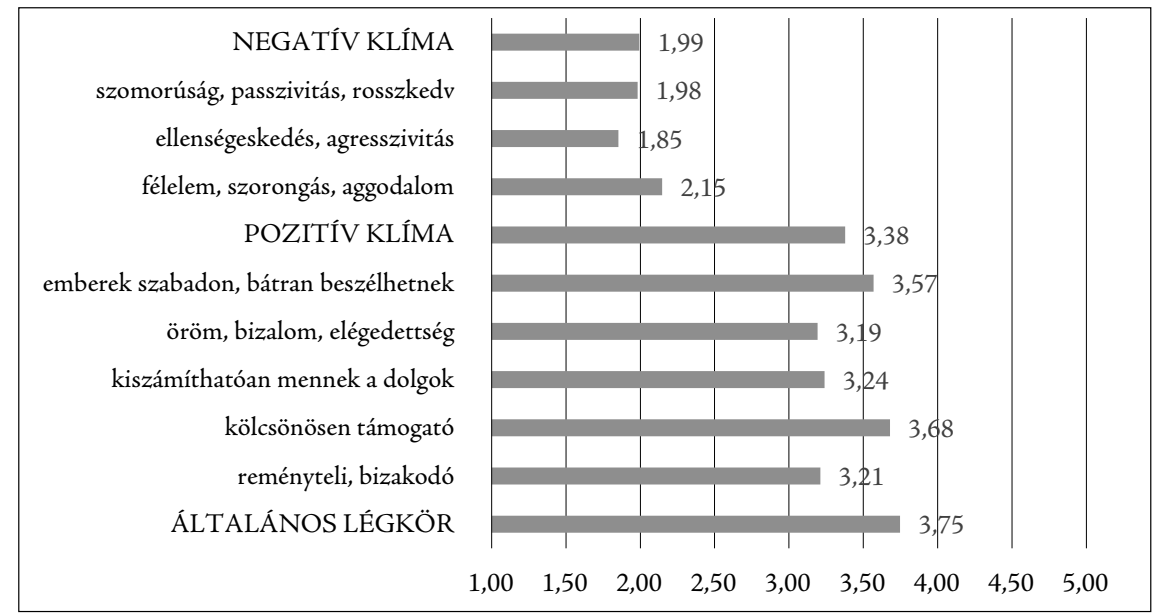

1. ábra: Az érzelmi légkör kérdőíves vizsgálatának átlagértékei

A negatív klímát „kissé” (átlag 1,99) tartják jellemzőnek, a válaszadók 11\%-a ítéli a közepesnél jellemzőbbnek ( 3 felett) azt. A negatív észlelésben a félelem, szorongás, aggodalom átlagos értékelése magasabb.

Összességében tehát inkább kedvező a légkör megítélése a válaszadóknál a kérdőíves vizsgálat alapján.

\section{A „Beszéljen öt percig szabadon a munkabelyéröl!” interjú elemzésének eredményei}

$\mathrm{A} z$ interjúkban kifejezett érzelmi valencia a szervezeti kapcsolatra vonatkozóan az összbenyomást tekintve 54,5\%-a pozitív, míg 45,5\%-a negatív minőséget fejezett ki. Az interjú első mondatainak érzelmi megítélése alapján viszont a válaszadók $25 \%$-a negatív, $46 \%$-a pozitív érzelmet fejezett ki, míg $29 \%$-a semleges volt.

A megjelenő érzelmek alapján a válaszadók közel fele kedvező érzelmekről számolt be a szervezettel kapcsolatosan, ami a bizalmi kapcsolat kedvező hatásával is összefügghet.

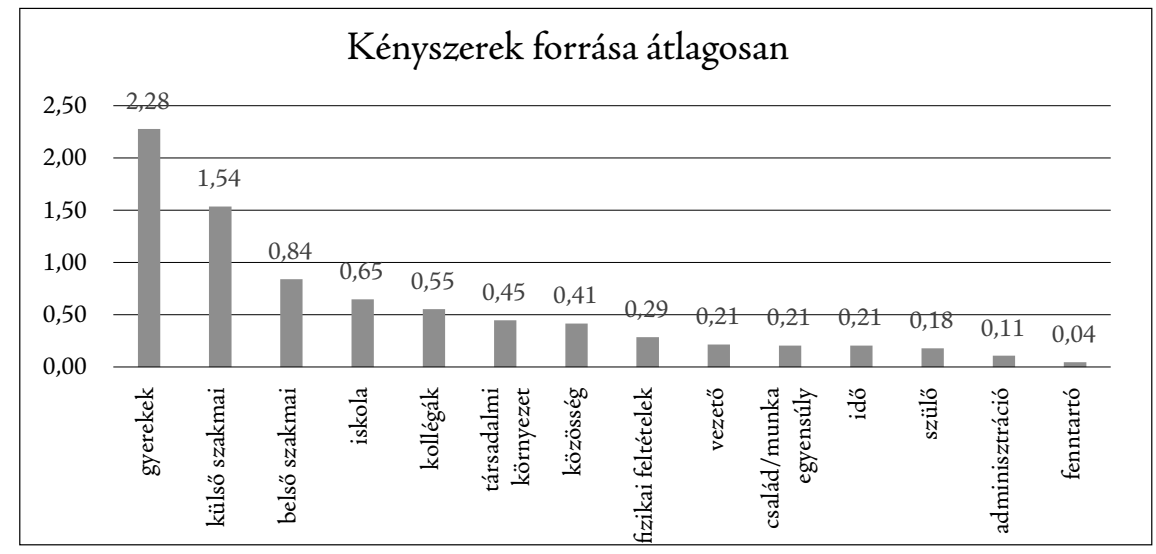

2. ábra: Kényszerek megjelenésének száma (említések átlaga/fö) 
A kérdőíves mérés alapján tapasztalt inkább kedvező légkör megítéléssel összhangban vannak az interjúeredmények.

A 112 válaszadónál 887 kényszer került azonosításra, s a válaszadók átlagosan 7,92 kényszerről számoltak be. A kényszer jelenléte - ha a személyen kívüli tényezőhöz kapcsolódik - a külsőleg kontrollált, nem belső indíttatású cselekvés, aktivitás jele, és a bizalom hiányára utalhat (2. ábra).

A kényszerek forrásánál leggyakrabban a gyerekekkel kapcsolatos elvárások, valamint a külső szakmai elvárások kényszerei jelentek meg (pl. érettségiztetés elvárások), majd ezt követte a belső szakmai elvárás (szakmai kötelezettség), az iskolához és a kollégákhoz kapcsolódó kényszerek gyakorisága. A későbbi elemzésekben a kényszerek közül a szakmai kötelezettség említését nem tekintettük kényszernek, ha a szövegkörnyezet alapján az ennek való megfelelést nem észlelte akadályozottnak a válaszadó. Lannert (2010, idézi Sass-Forgács 2015) korábbi, a tanári stresszforrásokra vonatkozó vizsgálatait elemezve is azt láttuk, hogy az észlelt korlátokkal kapcsolatos kontrollérzet nagymértékben befolyásolja a stresszkeltő értéket. Így például a kollégák, vezetés kontrollálható stresszforrásnak bizonyultak a korábbi vizsgálatban (alacsony stresszkeltő értékkel), a diákokkal kapcsolatos stresszt közepesnek, míg az oktatásirányítás elvárásai, az adminisztráció, a terhelés, a társadalmi elismerés hiánya és a szülők magas stresszkeltő értékünek bizonyultak az észlelt kontroll alacsony szintje miatt. Ennek megfelelően értékeltük az azonosított kényszereket is a vizsgálatban az észlelt kontroll szempontjából. ${ }^{5}$

A fentiek alapján a leggyakoribb kényszeremlítésekből a gyerekekhez és a belső szakmai elvárásokhoz magasabb, míg a külső szakmai elvárásokhoz alacsonyabb kontrollérzet társítható. Szintén gyakori a társadalmi környezet, a közösség és a fizikai feltételek említése, míg a vezető, a család és a munka egyensúlya, továbbá az idő mint kényszerforrások kevésbé gyakran jelennek meg.

A szándékot kifejező válaszból összesen 268 volt, ami válaszadónként átlagosan 2,39 szándékot kifejező választ jelent. Szándékként kódoltuk azokat a válaszokat, amelyek akaratot, szándékot fejeztek ki. Megkülönböztettük a szándéktartalmat aszerint, hogy abban benne volt-e a kontroll, az eredmény lehetősége vagy sem. (Például szándék kontrollal: „Gyerekek is, tanárok is próbáljuk a legjobbat kibozni, ami az eredményeinken látszik is.”; szándék kontroll nélkül: „Megpróbálom azt tenni, ahogyan sokszor látunk nagyon rossz sorsokat, hogy próbálunk empatikusnak lenni, mégis sokszor nem tudunk teljesíteni.")

A közösségre, a csoportra utaló többes szám használata 358, az átlagos gyakoriság 3,23 (lásd 3. ábra). Míg csak a többes szám első személyes névmás használata ritka, öszszesen 38 esetben fordult elő a szövegben, átlagosan 0,35 volt a megjelenés. ${ }^{6}$

\footnotetext{
A kényszerek kódolásához kapcsolódó néhány példát említek. A gyerekekhez kapcsolódó kényszer: „Nagyon sok a problémás gyerek, akibez nem tudok mindig úgy viszonyulni, mégis foglalkozni kell velük, nem mindig az oktatásról, hanem inkább a nevelésröl szól, az oktatás terén nagyon sok a kudarcélmény, nehéz az alapvető ismereteket is átadni, inkább kevesebbet kell átadni, de azt biztosan tudják reprodukálni." Külső szakmai kényszer: „El kell juttatni a gyerekeket az érettségire, ott nekik le kell vizsgázni." Míg a belső szakmai kényszer: „Ennek a gyereknek ez a továbbtanulás az egyetlen esélye az életben, ba én eltolom a felkészitését, akkor ennek a gyereknek még rosszabb lesz."

6 Közösségre utalás példája: „Itt a tantestület nagyon összetartó, mindig is ez volt, segitettük egymást, ha bármi problémánk volt, mindig tudtunk a másikról, bementünk órára, összejártunk fözöcskézni, kirándultunk." A T1 személyes névmás megjelenésére példa: „A visszacsatolás sajnos az nálunk sokkalta kevesebb, mint a régi iskolámban."
} 


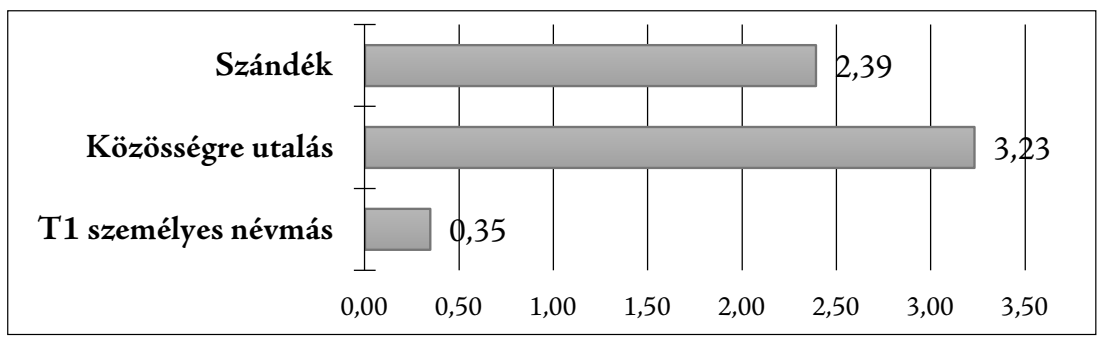

3. ábra: A szándék és közösségi érzés említések átlagos előfordulási gyakorisága

A vizsgált tartalmaknál a közös cselekvésre utaló kifejezések megjelenése a leggyakoribb, ezt követi a szándék megjelenése.

\section{A bizalom klíma nyelvi markereinek és a bizalom kvantitatív vizsgálatának összevetése}

Vizsgálatunk célja az előzetesen feltételezett bizalomra utaló nyelvi jelek feltérképezése mellett annak feltárása is volt, hogy ezen nyelvi jelek gyakorisága mutat-e együttjárást a bizalom klíma észlelésének kvantitatív értékelésével. Utóbbi vizsgálat a nyelvi jelek bizalom mérési célú használatának validálásához nyújthat támpontot. Ennek érdekében egyrészt együttjárásokat vizsgáltunk a kétféle mérési megközelítésnél, másrészt a magas és alacsony bizalomra vonatkozó észlelésnél összevetettük az előfordulások gyakoriságát.

\section{Az együttjárások vizsgálata}

A bizalomra utaló pozitív érzelmek, valamint a jelzett kényszerek egyes csoportjainál találtunk gyenge együttjárásokat a bizalom vonatkozású észleléseknél, ezt láthatjuk a 2. táblázatban.

A pozitív és negatív érzelmek megjelenése a szervezettel kapcsolatban a vizsgált klímajellemzők közül az „általános érzelmi légkör” kedvező vagy kedvezőtlen voltával, valamint a "folyamatok kiszámitható" megítélésével gyenge együttjárást mutat. Minél kedvezőbben megítélt a légkör, annál jellemzőbb az interjú vonatkozásában a pozitív összbenyomás megjelenése.

2. táblázat: Az érzelmi viszonyulás és légkör együttjárásai

\begin{tabular}{lcccc}
\hline & $\begin{array}{c}\text { Összbenyomás - Összbenyomás } \\
\text { negatív }\end{array}$ & $\begin{array}{c}1 . \text { mondat }- \\
\text { pozitív }\end{array}$ & $\begin{array}{c}1 . \text { mondat }- \\
\text { pozitív }\end{array}$ \\
\hline Általános érzelmi légkör & $-0,201^{*}$ & $0,201^{*}$ & $-0,241^{*}$ & \\
\hline Reményteli, bizakodó & & & & $0,216^{*}$ \\
\hline $\begin{array}{l}\text { Kölcsönösen segítő, támo- } \\
\text { gató, szolidáris }\end{array}$ & & $-0,255^{* *}$ & $0,200^{*}$ \\
\hline $\begin{array}{l}\text { Kiszámíthatóan mennek } \\
\text { a dolgok }\end{array}$ & $-0,250^{* *}$ & $0,250^{* *}$ & $-0,399^{* *}$ & $0,317^{* *}$ \\
\hline
\end{tabular}

${ }^{* \star}$ A korreláció $p<0,01 ;{ }^{*} p<0,05$ szinten szignifikáns. Csak a szignifikáns kapcsolatokat ismertetjük. 
A $z$ affektív töltet megítélésénél gyenge, de biztos a kapcsolat a pozitív első mondat és a "reményteli, bizakodó" hangulat, valamint a „dolgok kiszámithatóságának” észlelése között, míg gyenge pozitív a kapcsolat a „kölcsönös támogatás” észlelésével. A negatív első mondatnál gyenge, de biztos negatív kapcsolat van az „általános érzelmi légkör” kedvező észlelésével, a „kölcsönös támogatás”, valamint a „kiszámitható dolgok” észlelésével.

A 3, táblázatból a folyamatok kiszámíthatósága mutat együttjárást a megkérdezettek pozitív vagy negatív szervezeti viszonyulásával.

3. táblázat: A kényszerek észlelése és a légkör együttjárásai

\begin{tabular}{llccc}
\hline & $\begin{array}{l}\text { Általános érzelmi } \\
\text { légkör }\end{array}$ & $\begin{array}{l}\text { Kiszámíthatóan } \\
\text { mennek a dolgok }\end{array}$ & $\begin{array}{l}\text { Szomorúság, pasz- } \\
\text { szivitás, rosszkedv }\end{array}$ & $\begin{array}{l}\text { Öröm, bizalom, } \\
\text { elégedettség }\end{array}$ \\
\hline $\begin{array}{l}\text { Kényszer: } \\
\text { kollégák }\end{array}$ & & & $0,356^{* *}$ & $-0,254^{* *}$ \\
\hline $\begin{array}{l}\text { Kényszer: } \\
\text { külső szakmai }\end{array}$ & $-0,217^{*}$ & & \\
\hline
\end{tabular}

${ }^{* *}$ A korreláció $p<0,01$ szinten; ${ }^{*}$ Korreláció $p<0,05$ szinten szignifikáns. A táblázatban csak a szignifikáns kapcsolatokat jelenítettük meg.

A 3. táblázat alapján látható, hogy a gyakran említett, kisebb kontrollérzettel járó fizikai feltételek kényszer az „általános érzelmi légkörrel” és az „öröm, bizalom, elégedettség” észlelésével gyenge fordított korrelációt mutat. A szintén gyakori, alacsony kontrollérzettel társuló külső szakmai kényszerek a „kiszámíthatósággal” szintén gyenge negatív kapcsolatot mutatnak.

A kollégák vonatkozásában megélt kényszerkategória a „szomorúsággal, passzivitással” gyenge, de biztos pozitív kapcsolatban van, míg az „öröm, bizalom, elégedettséggel” negatív a kapcsolata. A kollégák vonatkozásában kontrollérzet feltételezhető a válaszadóknál, azonban a kedvezőtlen észlelés (kényszer) a bizalom szempontjából kiemelt fontosságú munkatársi törődés mint bizalomalap hiányára utalhat, illetve munkatársi bizalom hiányában megjelenhet a vonatkozó kényszerészlelés az együttjárás alapján.

A szándék és a közösségi érzés kategóriák vonatkozásában nem találtunk együttjárást egyik klímaösszetevővel sem.

\section{Bizalomszint szerinti csoportok összevetése}

Eltérést a csoportok között a kényszerek és a közösségi érzést jelző többes szám első személyt tartalmazó kifejezések gyakoriságánál tapasztaltunk.

Az együttjárások mellet $T$ próba segítségével összevetettük a kódolt tartalmi kategóriák említési gyakorisága szerint elkülöníthető csoportjainak klímaészlelését. Az eredményeket a 4. ábra mutatja. (Például kollégák mint kényszer említése magas és alacsony csoport összevetése.)

A z „öröm, bizalom, elégedettség” vonatkozásában erősen szignifikáns eltérést a kollégák és a fizikai feltételek mint kényszerek említésénél tapasztaltunk. Az alacsony bizalom magasabb említési gyakoriságot eredményezett. A „reményteli, bizakodó” légkört szintén 


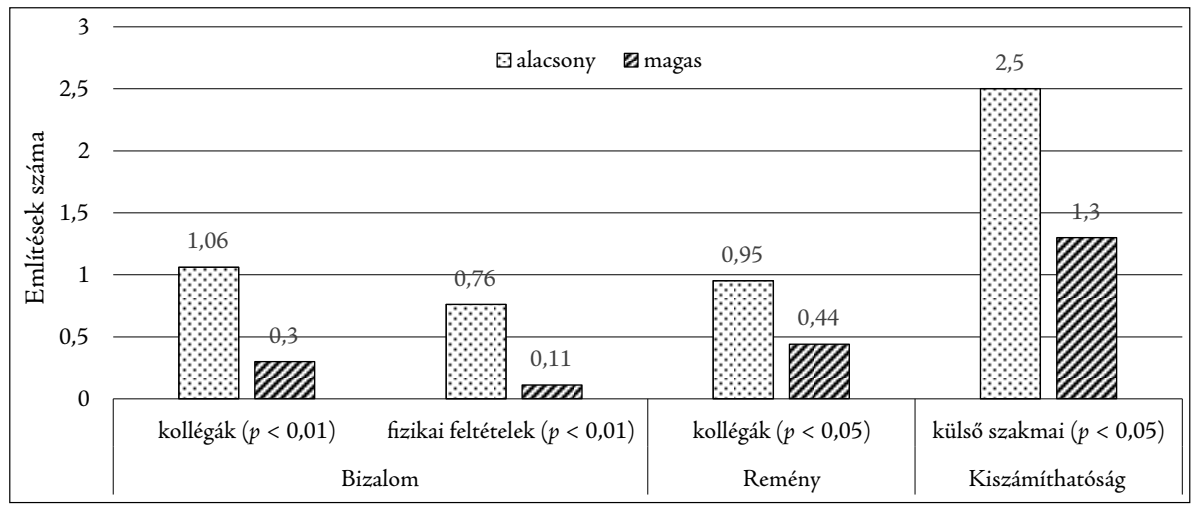

4. ábra: A szignifikáns eltérést mutató említések átlaga az egyes bizalom vonatkozású klímaterületeken magas és alacsony szintet mutató csoportoknál

a kollégák mint kényszer szignifikánsan magasabb említési átlaga jellemezte alacsonyabb szintnél. A "nálunk kiszámithatóan mennek a dolgok" alacsony észlelése szignifikánsan magasabb külső szakmai kényszeremlítéssel járt együtt, szemben a magas kiszámíthatósággal. Úgy tűnik, hogy a bizalom érzelmi oldalát jellemző bizalom és remény kedvező megélése a munkatársi kapcsolatok kedvező észlelésével és a fizikai feltételek biztosításával mutat kapcsolatot, míg a bizalom kognitív alapját képező kiszámithatóság a külső szakmai korlátok hiányában jelenik meg inkább.

Diszkriminanciaanalízis segítségével megvizsgáltuk a bizalomhoz kapcsolódó klímaterületeken magas és alacsony szinttel jellemezhető csoportok nyelvi markereinek átlagos előfordulását. A leggyakoribb kényszerkategóriák előfordulási gyakoriságánál csak azokat a területeket emeljük ki, ahol a fenti szignifikáns eltéréseken túl jelentős eltérés látható a két csoportnál az említések átlagos számában.

$\mathrm{Az}$ „öröm, bizalom, elégedettség” magas szintjét észlelők összességében kevesebb kényszert említenek, viszont a gyerekek mint kényszerforrás említése gyakoribb, ahogyan azt az 5. ábrán is láthatjuk. Ennek feltételezhető oka a már korábban is említett

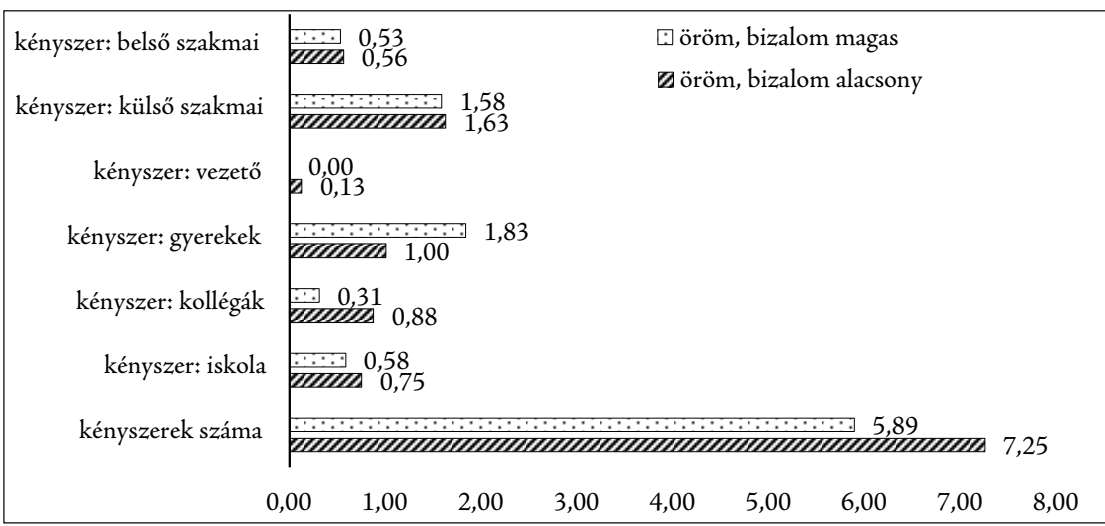

5. ábra: Kényszerkategóriák átlagos megjelenése az öröm és bizalom különböző szintjét érzékelőknél 


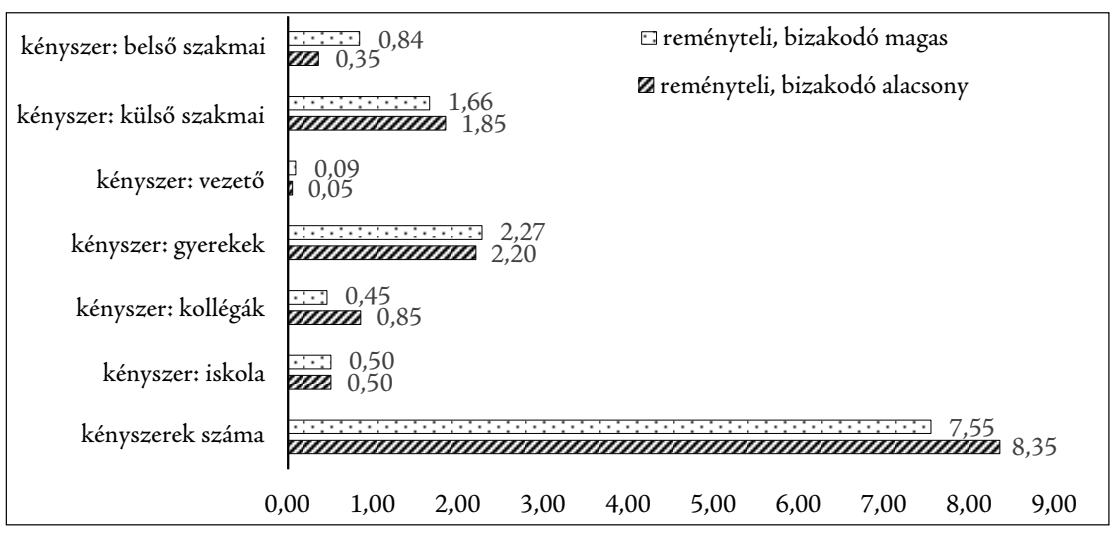

6 ábra: Kényszerkategóriák megjelenése a remény és bizakodás különböző szintjein lévőknél

magasabb tanári kontrollérzet, énhatékonyság észlelése a tanítással, tanulókkal kapcsolatban.

Remény, bizakodás magas szintjét mutató csoportnál szintén alacsonyabb az összes kényszeremlítés. További eltérés a belső szakmai kényszer (autonómia) magasabb átlagos említése, ami szintén az észlelt kontrollal mutathat összefüggést, ahogyan az a 6. ábrán is látható.

A kiszámíthatóság magas szintjének észlelése szintén kevesebb átlagos kényszeremlítéssel jár, míg az interjúkban kevésbé gyakran említett vezető oldaláról észlelt kényszer viszont magasabb. Ezt mutatja a 7. ábra. A bizalom kognitív alapjának tekinthető kiszámíthatóságészlelést támogatja a vezetői szabályozás észlelése, míg az alacsony kontrollérzettel járó külső szakmai korlátok $(p<0,05)$, illetve a magasabb kontrollérzettel társított diákok oldaláról a kényszerek észlelése csökkenti a bizalomkonzisztencián alapuló észlelhetőségét.

T próbával összevetettük a többes szám első személy használati gyakorisága alapján a képzett csoportokban (alacsony és magas említési gyakoriság) a három bizalom vonatkozású klímaterület értékelésének átlagait, szignifikáns eltérést nem tapasztaltunk, bár

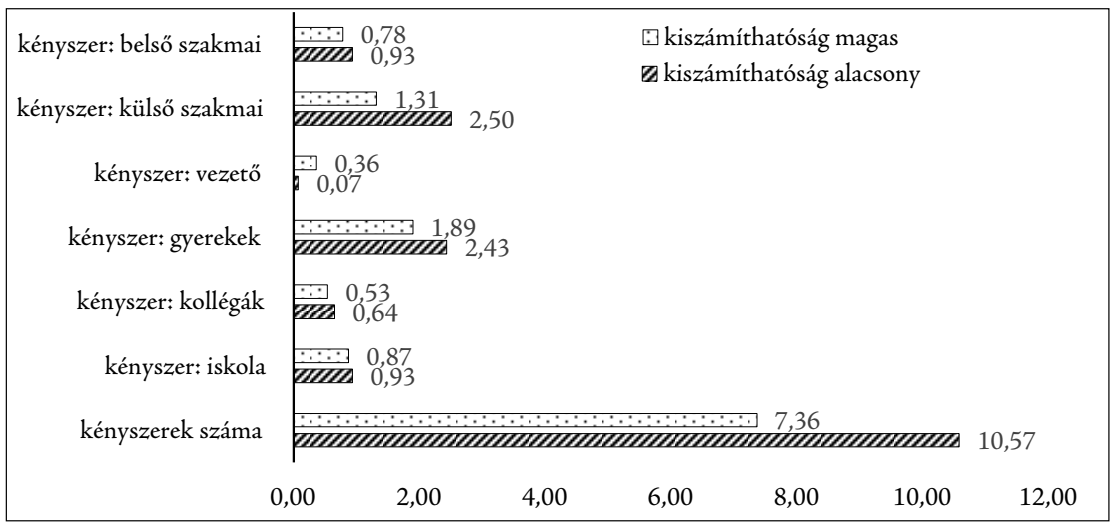

7. ábra: Kényszerkategóriák megjelenése a kiszámíthatóság különböző szintjein lévőknél 
a gyakoribb említés az „öröm, bizalom, elégedettség” észlelésének magasabb szintjével jár együtt.

\section{Megbeszélés}

Vizsgálatunkban a szervezeti bizalom klíma kvalitatív elemzését végeztük el. Ötperces beszédelemző eljárás segítségével a szervezettel kapcsolatban szabadon beszéltettük a megkérdezetteket, majd a szakirodalom alapján előzetesen azonosított kategóriákra vonatkozóan (pozitív szervezeti érzelmi tapasztalat, kényszer hiánya, közös szándék, mi tudat) tartalomelemzést végeztünk.

\section{Bizalom és pozitív érzelmi viszonyulás a szervezethez}

A bizalom nyelvi jeleire vonatkozóan tartalomelemzést végeztünk, az adatok értelmezése egyéni szinten történt. Megvizsgáltuk a kategóriák előfordulási gyakoriságát, valamint az együttjárásokat a szervezeti bizalom kérdőíves vizsgálatának adatait felhasználva. További vizsgálatunk a magas és alacsony bizalomszintet mutató csoportok összehasonlítását célozta a bizalom verbális markereinek előfordulási gyakoriságára vonatkozóan.

Összességében a bizalom kvalitatív és kvantitatív mérése alapján jelentős eltérést nem tapasztaltunk. A kedvező érzelmeket mindkét vizsgálati módszerrel inkább jellemzőnek találtuk a megkérdezetteknél, ugyanakkor az interjú módszer első gondolati tartalmát figyelembe véve a válaszadók közel harmadánál negatív megítélést találtunk, míg a kérdőíves módszerrel a közepesnél erősebb negatív megítélés csupán a válaszadók $11 \%$-ánál volt jellemző. A kvalitatív mérés előnye a kedvezőtlen érzelmi viszonyulás detektálhatóságában, valamint elsősorban az első azonosítható gondolati tartalom valenciája alapján a bizalom alapjának azonosításánál (kiszámíthatóság, kölcsönös támogatás, illetve pozitív valenciánál a remény megléte vagy hiánya) mutatkozott meg.

\section{Bizalom és külsö kényszer hiányának észlelése a szervezetben}

A kényszer forrásainak azonosítása nyomán elkülönítettük a külső és belső forrásokat, valamint azt is figyelembe vettük az elemzésnél, hogy a korábbi vizsgálatok alapján az egyes források mekkora kontrollérzettel jellemezhetők a tanári pályán.

Gyakoriság szerint a gyerekek, külső szakmai elvárás, belső szakmai elvárás, az iskolához és a kollégákhoz kapcsolódó kényszerek jelzése fordult elő nagyobb számban. A kedvező szervezeti érzelmi viszonyulásnak megfelelően a szervezeti bizalomra utaló említések (pl. diákok, belső szakmai kényszer) gyakoriak. A bizalom kognitív és érzelmi összetevői szerint eltérő bizalomtárgyak vonatkozásában jelentek meg a kényszerre utaló nyelvi markerek. A kiszámithatóság mint kognitív bizalomalap a vezetői kényszer említésében és a külső szakmai kényszer, a diákokkal kapcsolatos kényszer észlelésének hiányában mutatkozik meg. A bizalom és jövőre vonatkozó remény mint érzelmi bizalomalap elsősorban a kollégákkal kapcsolatos kényszer hiányában jellemző. Továbbá a bizalom a fizikai feltételek biztosítottságánál és a kezelhető diákok felől észlelt kényszer mellett, míg a remény a személyes hatékonyságra utaló belső szakmai kényszerek említésekor valószínübb. 


\section{Bizalom és közösségi érzés, közös érdekek megjelenése a szervezetben}

A vizsgált tartalmaknál a közös cselekvésre, szándékra utaló kifejezések megjelenése gyakori, azonban a szándék és a közösségi érzés kategóriák vonatkozásában nem találtunk együttjárást a klímaösszetevőkkel. A bizalom érzelmi alapját jelző közösségi érzésre, a bizalom közös érdekeket előtérbe helyező szerepére utaló „mi” szóhasználati mód a bizalom érzelmi alapjának tekinthetö „öröm, bizalom, elégedettség” észlelésével mutatott gyenge együttjárást.

Összegezve: eredményeink azt mutatják, hogy a szervezeti bizalom kvalitatív vizsgálatára alkalmas módszer a rövid szabad beszédmintavételi eljárás. A bizalom feltételezett jelei: a pozitív érzelmek, a kényszer hiánya és a közösségi érzés, érdekek a szóhasználat alapján értékelhető, mérhető. Az azonosított nyelvi markerek a bizalom kognitív és érzelmi alapjai szerint eltérhetnek.

A kognitiv bizalmat megalapozó kiszámíthatóság a kedvező érzelmi viszonyulásban, a vezetői kényszer elfogadásában, a külső szakmai kényszerek, diákokkal kapcsolatos kényszerek említésének hiányában detektálható.

A z érzelmi bizalomalapok észlelhető forrásai a kollegiális kényszer és a fizikai feltételek miatti kényszer hiánya és a kompetenciaérzet. Utóbbi a diákokra vonatkozó kezelhető kényszer vagy az autonómiára utaló belső szakmai kényszer jelenlétében mutatkozik meg. Szintén jelzi ezen bizalomalap jelenlétét a közös megoldások, érdekek előtérben állására utaló többes szám első személyű szóhasználat gyakorisága.

\section{Kitekintés}

Feltáró vizsgálatunk az oktatási intézmények bizalom klímájának kvalitatív mérésére tett kísérletnek tekinthető. A korábbi megterhelő kérdőíves vizsgálatok alternatíváját kínálja ez a megközelítés és első lépésként sikeresen azonosít olyan verbális markereket, amelyek a tanárok intézményükkel kapcsolatos bizalmának mérésére alkalmasak.

A bizalom vonatkozásában a kollégák, a külső és belső szakmai kényszer, a diákok, a fizikai feltételek és a vezető vonatkozásában jelennek meg azonosítható tartalmak. Utóbbi vonatkozásában meglepően alacsony az említések száma, annak ellenére, hogy az oktatási intézmények klímája szempontjából a munkatársi kapcsolatok mellett meghatározó szerepü a vezetö (Tschannen-Moran-Gareis 2015).

A vizsgálat alapján elkülöníthető a bizalom kognitív alapját jelző kiszámíthatóság és az érzelmi bizalomalapra utaló öröm, bizalom, elégedettség és remény nyelvi jelzéseinek megjelenése. A további vizsgálatok célja ezen markerek további lebontása, finomítása, az egyes markerek „súlyának” megállapítása, valamint a szervezeti szintü bizalommérés módszereinek kialakítása.

Az Ötperces interjú eljárás más területeken történő alkalmazásánál az egyik fejlesztési irány a félig strukturált interjú, a tematikus kérdések alkalmazása (Sher-Censor 2015). Amennyiben feltárhatók a bizalom szempontjából kiemelt területek, az interjú strukturálásának irányai is kijelölhetők, illetve a különböző oktatási intézménytípusok, intézményi szereplők (diákok, vezetők, szülők, adminisztrátorok) szerint specifikálható a bizalom klíma fókusza.

A rövid interjú alkalmazása több szempontból előnyös lehet a szervezeti bizalomvizsgálatoknál. A bizalom és klíma dinamikusan változó volta a kérdőíves mérésekkel nehe- 
zen követhető nyomon, míg a „beszélgetés” természetes helyzetnek tekinthető, többször ismételhető eljárás.

\section{IRODALOM}

Breeman, G. (2012) 15 Hermeneutic Methods in Trust Research. In: F. Lyon, G. Möllering \& M. N. Saunders (eds) Handbook of Research Methods on Trust. Edward Elgar Publishing. pp. 149-160.

Butler Jr., J. K. (1999) Trust Expectations, Information Sharing, Climate of Trust, and Negotiation Effectiveness and Efficiency. Group E Organization Management, Vol. 24. No. 2. pp. 217-238.

Costa, A. C., Fulmer, C. A. \& Anderson, N. R. (2017) Trust in Work Teams: An Integrative Review, Multilevel Model, and Future Directions. Journal of Organizational Behavior, Vol. 39. No. 2. pp. 169-184.

De Rivera, J. (1992) Emotional Climate: Social Structure and Emotional Dynamics. In: K. T. Strongman (ed.) International Review of Studies on Emotion, Vol. 2. New York, Wiley. pp. 199-218.

De Rivera, J. \& Páez, D. (2007) Emotional Climate, Human Security, and Cultures of Peace. Journal of Social Issues, Vol. 63. pp. 233-253.

Ehmann B., Csertő I., Ferenczhalmy R., Fülöp É., Hargitai R., Kővágó P., Pólya T., Szalai K., Vincze O. \& László J. (2014) Narratív kategoriális tartalomelemzés: a NARRCAT, X. Magyar Számítógépes Nyelvészeti Konferencia. http://real.mtak. hu/20127/7/jav_MSZNY2014_press_b5.pdf [Letöltve: 2018. 08.30.]

Ferenczhalmy, R., \& LÁszló, J. (2010) In-group versus out-group intentionality as indicators of national identity. Empirical Text and Culture Research, Vol. 4. pp. 59-69.

Fiol, C. M. (2002) Capitalizing on Paradox: The Role of Language in Transforming Organizational Identities. Organization Science, Vol. 13. No. 6. pp. 653-666.

Gambetta, D. \& Hamill, H. (2005) Streetwise: How Taxi Drivers Establish Customer's Trustworthiness. Russell Sage Foundation.

Goddard, R. G., Hoy, W. K. \& Woolfolk Hoy, A. (2004) Collective Efficacy: Theoretical Development, Empirical Evidence, and Future Directions. Educational Researcher, Vol. 33. pp. 3-13.

Halász G. (1980) Az iskolai szervezet elemzése. Kutatási beszámoló az iskolai szervezeti klíma vizsgálatáról. Budapest, MTA.

Kiss I. (2009) (ed.) Életvezetési Kompetencia. http://pszichologia.phd.elte.hu/vedesek/2009/ PHD_tezisek_Kiss_Istvan.pdf [Letöltve: 2010. 04.11.]

László, J., Csertő, I., Fülöp, É., Ferenczhalmy, R., Hargitai, R., Lendvai, P., Péley, B., Pólya, T., Szalai, K., Vincze, O. \& Ehmann, B. (2013) Narrative Language as Expression of Individual and Group Identity: The Narrative Categorical Content Analysis (NarrCat). Sage Open, Vol. 3. No. 2. 2158244013492084 . http://sgo.sagepub. com/content/3/2/2158244013492084 [Letöltve: 2015. 06. 12.]

Lyon, F., Möllering, G. \& Saunders, M. N. (2015) Introduction: The Variety of Methods for the Multi-faceted Phenomenon of Trust. In: F. Lyon, G. Möllering \& M. N. Saunders (eds) Handbook of Research Methods on Trust. Edward Elgar Publishing. pp. 1-24.

Magaña, A. B., Goldstein, J. M., Karno, M., Miklowitz, D. J., Jenkins, J. \& Falloon, I. R. (1986) A Brief Method for Assessing Expressed Emotion in Relatives of Psychiatric Patients. Psychiatry Research, Vol. 17. No. 3. pp. 203-212. 
Martínez-Tur, V. \& Peiró, J. M. (2009) The Trust Episode in Organizations: Implications for Private and Public Social Capital. Social Science Information, Vol. 48. No. 2. pp. 143-174.

Mатsumoto, D. (1990) Cultural Similarities and Differences in Display Rules. Motivation and Emotion, Vol. 14. No. 3. pp. 195-214.

Mayer, R. C., Davis, J. H. \& Schoorman, F. D. (1995) An Integrative Model of Organizational Trust. Academy of Management Review, Vol. 20. pp. 709-734.

McAllister, D. J. (1995) Affect- and Cognition-based Trust as Foundations for Interpersonal Cooperation in Organizations. Academy of Management Journal, Vol. 38. No. 1. pp. 24-59.

McKnight, D. H. \& Chervany, N. L. (1996) The Meanings of Trust. http://citeseerx.ist. psu.edu/viewdoc/download;jsessionid=1E34CCC9C808B28B9631D5E65994BB08?doi $=10.1 .1 .155 .1213 \& \mathrm{rep}=$ rep1\&type $=$ pdf [Letöltve: 2018.09 .10 .]

Mullins, L. J. (1993) Management and Organizational Behaviour. 3rd edition. London, Pitman Publishing.

Ning, L. I. \& Jin, Y. A. N. (2009) The Effects of Trust Climate on Individual Performance. Frontiers of Business Research in China, Vol. 3. No. 1. pp. 27-49.

OláH, A. (2006) Érzelmek, megküzdés és optimális élmény. Budapest, Trefort Kiadó.

Paez, D., Ruiz, J. I., Gailly, O., Kornbilt, A. L., Wisenfeld, E. \& Videl, C. M. (1997) Clima emocional: Su concepto y medición mediante una investigación transcultura. Revista de Psicología Social, Vol. 1. No. 12. pp. 79-98.

Parkinson, B., Fischer, A. H. \& Manstead, A. S. R. (2005) Emotion in Social Relations: Cultural, Group, and Interpersonal Processes. New York, Psychology Press.

Sass, J. (2005) Bizalom a szervezetekben. In: Faragó K. És Kovács Z. (eds) Szervezeti látleletek. A szervezetpszichológia hazai kutatási irányai. (Pszichológiai Szemle Könyvtár, 9.) Budapest, Akadémiai Kiadó. pp. 7-27.

SAss J. (2008) A vezetőbe vetett bizalom és annak hatása a bizalmi döntésekre. A bizalom csapdája. In: Erős F. (ed.) Megismerés, reprezentáció, értelmezés. 10 éves a PTE Pszichológiai Doktori Iskolája. Pécs, PTE.

SAss J. (2011) Szervezeti érzelmek és szervezeti bizalom. Tananyag. http://www.uni-corvinus. hu/index.php?id=44127 [Letöltve: 2015. 05. 08.]

Sass J., Bodnár É. \& KöPeczi-Bócz T (2015) Érzelmi igénybevétel a tanári pályán. In: Daruka M. (ed.) A tanári szerep változásának háttértényezöi a szakképzésben. Budapest, Budapesti Corvinus Egyetem. pp. 36-73.

SAss J. \& Forgács A. (2015) A stressz kezelése a pedagóguspályán. Budapest, Budapesti Corvinus Egyetem, e-tananyag. pp. 1-68.

Schneider, B., Ehrhart, M. G. \& Macey, W. H. (2013) Organizational Climate and Culture. Annual Review of Psychology, Vol. 64. pp. 361-388.

Schwarzer, R., Schmitz, G. S. \& Daytner, G. T. (1999) Collective Teacher Self-efficacy. http://userpage.fu-berlin.de/gesund/skalen/Language_Selection/Turkish/Collective_ Teacher_Self-Effica/hauptteil_collective_teacher_self-effica.htm [Letöltve: 2015. 05. 15.]

Shamir, B. \& Lapidot, Y. (2003) Trust in Organizational Superiors: Systemic and Collective Considerations. Organization Studies, Vol. 24. pp. 463-492.

Sher-Censor, E. (2015) Five Minute Speech Sample in Developmental Research: A Review. Developmental Review, Vol. 36. pp. 127-155. 
Tasa, K., Taggar, S., Sejits, G. H. (2007) The Development of Collective Efficacy in Teams: A Multilevel and Longitudinal Perspective. Journal of Applied Psychology, Vol. 91. No. 1. pp. 17-27.

Thapa, A., Cohen, J., Guffey, S. \& Higgins-D’Alessandro, A. (2013) A Review of School Climate Research. Review of Educational Research, Vol. 83. No. 3. pp. 357-385.

Tschannen-Moran, M. \& Gareis, C. R. (2015) Faculty Trust in the Principal: An Essential Ingredient in High-Performing Schools. Journal of Educational Administration, Vol. 53. No. 1. pp. 66-92.

Tyler, T. R. (1989) The Psychology of Procedural Justice: A Test of the Group-Value Model. Journal of Personality and Social Psychology, Vol. 57. No. 5. pp. 334-340.

Wang, M. T. \& Degol, J. L. (2016) School Climate: A Review of the Construct, Measurement, and Impact on Student Outcomes. Educational Psychology Review, Vol. 28. No. 2. pp. 315-352.

Wiesenfeld, E., Kornblit, A., Vidal, C. M., Ruiz, J. I., Páez Rovira, D. \& Gailly, O. (1997) Clima emocional: su concepto y medición mediante una investigación transcultural. Revista de Psicología Social, Vol. 12. No. 1. pp. 79-98.

Yurtsever, G. \& De Rivera, J. (2010) Measuring the Emotional Climate of an Organization. Perceptual and Motor Skills, Vol. 110. No. 2. pp. 501-516.

A cikk a Creative Commons Attribution 4.0 International License (https://creativecommons.org/licenses/ by/4.0/) feltételei szerint publikált Open Access közlemény, melynek szellemében a cikk bármilyen médiumban szabadon felhasználható, megosztható és újraközölhető, feltéve, hogy az eredeti szerző és a közlés helye, illetve a CC License linkje és az esetlegesen végrehajtott módosítások feltüntetésre kerülnek. (SID_1) 